Article

\title{
Precipitation and Temperature in Costa Rica at the End of the Century Based on NEX-GDDP Projected Scenarios
}

\author{
Rodrigo Castillo *(i) and Jorge A. Amador (1) \\ School of Physics and Center for Geophysical Research, University of Costa Rica, San José 11501, Costa Rica; \\ jorge.amador@ucr.ac.cr \\ * Correspondence: rodrigo.castillorodriguez@ucr.ac.cr
}

Received: 26 October 2020; Accepted: 23 November 2020; Published: 7 December 2020

\begin{abstract}
The evaluation of intraseasonal, seasonal, and annual variability of rainfall and temperature extremes, while using climate change scenarios data, is extremely important for socio-economic activities, such as water resources management. Costa Rica, a climate change hotspot, is largely dependent on rainfall for socioeconomic activities; hence, the relevance of this study. Based on the NEX-GDDP, rainfall and temperature range were analyzed for Costa Rica at the end of the century (2070-2099), while using 1970-1999 as a baseline for six available meteorological stations. Differences between the multimodel ensembles of two prospective scenarios (RCP 4.5 and 8.5) and the historical information were computed. This study highlights Costa Rica as an inflexion region for climate change impacts in Central America, for which projected scenarios suggest an early onset of the rainy season, and a decline in the mid-summer drought (MSD) minimum. The assessment of model data in some regions of Costa Rica, for which historical data were available, suggests that the latter does not capture a well-known regional climate feature, the MSD, in both precipitation and temperature range well. The availability of observed past data sources is a major limitation of this research; however, with the station data used, it is still possible to draw some conclusions regarding future climate in some regions of Costa Rica, especially in the northwest side of the country, where past data are consistent with model information, providing a more reliable picture of changes in climate there that has potential implications for socioeconomic sectors.
\end{abstract}

Keywords: climate change; Costa Rica; NEX-GDDP; precipitation; RCP 4.5; RCP 8.5; temperature

\section{Introduction}

Costa Rica is located in the Central American Isthmus, which is the only region in the world whose position is both intercontinental (uniting two great continental masses, North and South America) and interoceanic (putting two oceans into communication, Pacific, and Atlantic Oceans [1]. Its geographical location in the tropics contributes to a unique climate that nurtures rich biodiversity, allowing for the creation of a receptive and positive environment for international conservation investment [2]. This has turned Costa Rica into a pioneer country in the environmental service payment system by establishing a formal country-wide subsidy program. Costa Rica has made substantial progress in charging water consumers, although there has been more limited progress in doing that for biodiversity and carbon sequestration users [3]. This preservation scheme, in which farmers receive payments for protecting existing forests and integrating trees into their agricultural practices, has served as a regional model [4-6]. Similar schemes are now being developed in Honduras, Guatemala, Mexico, and Nicaragua [6,7]. Costa Rican environmental protection policies have alleviated poverty in communities close to protected areas [8] and contribute to the national commitment to becoming 
carbon-neutral before 2021 [9], a task that, for many sectors, is difficult to reach. One of the most important aspects for the Costa Rican progress would be the appropriate interaction between the earth sciences community and policy makers, through the knowledge exchange and transfer on how Costa Rica may respond to determine their future economic, financial, and human development, as well as their environmental and social well-being.

The country's climate is characterized by a strong influence of the trade winds, so that their interaction with local circulations and orography generates different regimes of precipitation that broadly determine two types of ecosystems: the dry and rainy tropical forests. The trade winds are associated, on average, with two different rainfall regimes, one on the Caribbean and the other on the Pacific slope of the country [10-12]. There is a bimodal distribution of precipitation on the Pacific side, featured by a dry season from November to April and a rainy season from May to October, which responds to a combination of systems that involve the latitudinal migration of the intertropical convergence zone (ITCZ), the seasonal variation of incoming solar radiation, and the low level winds that interact with regional and local circulations and topography [13-16]. This bimodal distribution of precipitation has two maxima, one in May-June, a more pronounced peak in September-October, and a relative minimum in July-August [17-19], which is regionally known as «veranillo» or midsummer drought (MSD; $[20,21])$.

In contrast, the Caribbean side portrays an almost continuous annual rainfall regime along coastal areas. Over this region, precipitation increases from south to north, reaching a coastal and maritime peak, close to the Costa Rica and Nicaragua border, that has been associated with the the Caribbean Low-Level Jet (CLLJ; [22,23]) exit. Over inland regions the main factors modulating rainfall are the convective activity and the flow interaction with the mountain range. At the local scale, there are particularities affecting precipitation distribution like the existence of sea-breeze and valley-mountain circulations [24]. The country also exhibits arid zones in the Caribbean contrasting with heavy rainy areas in the Pacific side [11,12].

A key climate driver for Costa Rican weather and climate is the North Atlantic Subtropical High (NASH [25-27]) modulating the trade wind intensity close to the equatorial flank [16]. Other synoptic scale mechanisms influencing Costa Rican atmospheric conditions are: (1) the ITCZ seasonal migration, which mainly affects the Pacific side [28-30]; (2) the incursion of cold fronts originating in middle latitudes [31-34]; and, (3) the westward propagation of tropical disturbances. The junction of those mechanisms and related physical processes define the regional seasonality of rainfall, which is often characterized by heavy rainfall in the Caribbean region [35]. Studies of rainfall distribution over Central America date back to the mid-twentieth century $[10,36]$ and they show a unique variety of annual cycles. Large scale precipitation is controlled by the orientation of the mountains and configuration of the coast lines relative to the seasonal wind flow patterns. More recent works show that other atmospheric forcings influence precipitation on regional scales, including the CLLJ [22,23], the regional sea surface temperature (SST) distribution [21,37], and the major tropical variability modes, namely: (a) Quasi-biennial Oscillation (QBO; [38,39]); (b) Madden-Julian Oscillation (MJO; [40-42]); (c) the El Niño Southern Oscillation (ENSO; [43-45]); (d) the Arctic Oscillation (AO; [31,45]); and, (e) the Antarctic Oscillation (AAO; [45]).

In regard to the use of the NASA Earth Exchange Global Daily Downscaled Projections (NEX-GDDP) dataset for climate projections for different society sectors, most of the work has been done in Asia (i.e., [46-52], and papers therein), Africa (i.e., [53,54], and papers therein), North America (i.e., [55,56]), and South America (i.e., [57,58], and papers therein). In Central America, which is the region of interest, relatively few studies have been reported using projections of climate data. Giorgi [59] was among the first to report Central America as a hotspot region for climate change impacts, in the form of a reduction in precipitation and a increase in precipitation variability. This result was later confirmed by Diffenbaugh and Giorgi [60] while using the Coupled Model Intercomparison Project Phase 5 (CMIP5; [61,62]) data. Despite the relevance of this climate warning, relatively few studies have been conducted in the region in regard to future climate change projections. Hidalgo et al. [63] 
calculated runoff climate change projections for the twenty-first century from a suite of 30 General Circulation Model (GCM) simulations for the A1B emission scenario in a $0.5^{\circ}$ by $0.5^{\circ}$ grid over Central America. Their main findings, of interest to this work, are that projected climate in the 2050-2099 period showed median significant reductions in precipitation (as much as $5-10 \%$ ) and runoff (as much as 10-30\%) in northern Central America (Guatemala, El Salvador and Belize), with no definite changes in other regions. In a more recent paper, Hidalgo et al. [64] found, while using CMIP5 data, that Panama is projected to be wetter in the future than the current climate by the mid of the twenty-first century, with Costa Rica being a region with no clear signal (see Figure 4 of the above paper). Maurer et al. [65] used historical gridded precipitation data and future projections to analyze the MSD. Their results, which are valid for most of the Pacific side of Central America, showed a decrease in the MSD minimum precipitation by the end of the twenty-first century. Recently, Gutierrez et al. [55] and Iwamura et al. [56] have employed NEX-GDDP data to analyze projected climate scenarios for public health applications. The latter work estimated the invasion potential of disease vector Aedes aegypti under climate change for several regions of the world, including Central America. Their findings for tropical areas presented a particularly high level of strong increases in the number of generations of the vector, a result that suggest the importance of implementing adaptation and mitigation strategies in this part of the world. Depsky and Pons [66] downscaled CMIP5 GCMs for different time scales to the analyzed projected dry patterns for the Central America Dry Corridor (CADC, [67]). Their results suggest a pronounced scenario in the length of the seasonal-scale droughts, such as the MSD.

One of the objectives of this research is to assess the potential applications of projected model data (NEX-GDDP) for future climate impacts in Costa Rica, especially in regions that are known to suffer dry spells on a seasonal and annual basis [63-65,67]. Another objective is to include in the analysis other regions of Costa Rica, such as the Caribbean and southwestern part of the country, which have been less studied in that respect. Last but not least, the authors also aim to continue the preparation of historical station data for comparison with model data in a region that is known to be deficient in data availability for climate studies [63-65,67].

\section{Data and Methodology}

\subsection{Climate Scenarios}

The NEX-GDDP dataset is composed of downscaled climate scenarios for the globe that is derived from the GCM runs conducted under CMIP5. The NEX-GDDP dataset includes statistical downscaled projections for Representative Concentration Pathways (RCPs; [68,69]) 4.5 and 8.5 scenarios from 21 models (see Table 1), for which daily scenarios were produced and distributed under CMIP5.

The RCPs scenarios provide information on the possible development trajectories of the main forcing agents of climate change, such as greenhouse gases [69]. The RCP 4.5 refers to the stabilization of the radiative forcing at $4.5 \mathrm{~W} \cdot \mathrm{m}^{-2}$ in the year 2100 without ever exceeding that value (approximately $650 \mathrm{ppm}$ of $\mathrm{CO}_{2}$ ). This scenario includes long-term, global emissions of greenhouse gases, short-lived species, and land-use-land-cover in a global economic framework [70-74]. The RCP 8.5 corresponds to concentrations of $1370 \mathrm{ppm}$ of $\mathrm{CO}_{2}$, which makes it the route with the highest greenhouse gas emissions. This scenario combines assumptions regarding high population and relatively slow income growth with modest rates of technological change and energy intensity improvements, leading, in the long-term, to a high energy demand and greenhouse gas emissions in the absence of climate change policies [74-76]. The NEX-GDDP dataset is provided in order to assist the scientific community in conducting studies of climate change impacts at the local to regional scales, and enhance public understanding of possible future global climate patterns at the spatial scale of individual towns, cities, and watersheds. This dataset has a bias-corrected global grid with a high spatial $(25 \mathrm{~km} \times 25 \mathrm{~km})$ and daily temporal resolution. It covers a period from 1950 to 2100, divided into two sub-periods, one from 1950 to 2005 (retrospective baseline) and the other one from 2006 to 2100 (prospective scenario) for the 
variables of precipitation, and maximum $\left(t_{\max }\right)$ and minimum $\left(t_{\min }\right)$ near-surface air temperature [77]. In this study, data for the RCP 4.5 and 8.5 was used in order to evaluate how rainfall and temperature over Costa Rica is projected to change at the end of the century (2070-2100). Additionally, with these variables, the diurnal temperature range $(D T R)$ was derived as (Equation (1)).

$$
D T R=t_{\max }-t_{\min }
$$

Table 1. CMIP5 General Circulation Models (GCMs) used to generate the NASA Earth Exchange Global Daily Downscaled Projections (NEX-GDDP) dataset.

\begin{tabular}{|c|c|}
\hline Model & Modeling Center \\
\hline ACCESS1-0 & $\begin{array}{l}\text { Commonwealth Scientific and Industrial Research Organization } \\
\text { and Bureau of Meteorology, Australia }\end{array}$ \\
\hline BCC-CSM1-1 & Beijing Climate Center, China Meteorological Administration, China \\
\hline BNU-ESM & $\begin{array}{l}\text { College of Global Change and Earth System Science, } \\
\text { Beijing Normal University, China }\end{array}$ \\
\hline CanESM2 & Canadian Centre for Climate Modeling and Analysis, Canada \\
\hline CCSM4 & National Center for Atmospheric Research, United States \\
\hline CESM1-BGC & Centro Euro-Mediterraneo sui Cambiamenti Climatici, Italy \\
\hline CNRM-CM5 & National Centre for Meteorological Research, France \\
\hline CSIRO-MK3-6-0 & $\begin{array}{l}\text { Commonwealth Scientific and Industrial Research Organization } \\
\text { and Queensland Climate Change Centre of Excellence, Australia }\end{array}$ \\
\hline GFDL-CM3 & NOAA/Geophysical Fluid Dynamics Laboratory, United States \\
\hline GFDL-ESM2G & \\
\hline GFDL-ESM2M & \\
\hline INMCM4 & Institute for Numerical Mathematics, Russia \\
\hline $\begin{array}{l}\text { IPSL-CM5A-LR } \\
\text { IPSL-CM5A-MR }\end{array}$ & L'Institut Pierre-Simon Laplace, France \\
\hline MIROC-ESM & $\begin{array}{l}\text { Atmosphere and Ocean Research Institute (The University of Tokyo), } \\
\text { National Institute for Environmental Studies, and Japan Agency for } \\
\text { Marine-Earth Science and Technology, Japan }\end{array}$ \\
\hline $\begin{array}{l}\text { MIROC-ESM-CHEM } \\
\text { MIROC5 }\end{array}$ & \\
\hline MPI-ESM-LR & Max Planck Institute for Meteorology, Germany \\
\hline MPI-ESM-MR & \\
\hline MRI-CGCM3 & Meteorological Research Institute, Japan \\
\hline NorESM1-M & Norwegian Climate Center, Norway \\
\hline
\end{tabular}

Table 2 summarizes the specifications of this dataset used to carry out the aims of this research.

Table 2. Dataset specifications.

\begin{tabular}{ll}
\hline Dataset & $\begin{array}{l}\text { NASA Earth Exchange Global Daily } \\
\text { Downscaled Projections (NEX-GDDP) }\end{array}$ \\
\hline Size & $12 \mathrm{~TB}$ \\
Spatial Resolution & $0.25^{\circ} \times 0.25^{\circ}$ \\
Temporal Range & $1950-2005$ historical \\
& $2006-2100$ RCP 4.5 and 8.5 \\
Variables & $p r, t_{\max }, t_{\min }$ \\
Reference & Thrasher and Nemani [77] \\
\hline
\end{tabular}

The Bias-Correction Spatial Disaggregation (BCSD) method that is used to generate the NEX-GDDP dataset is a statistical downscaling algorithm specifically developed for addressing the current limitations of global output from GCMs [78-81]. These limitations are related to (a) the coarse resolution grids used in most GCM runs (e.g., a few degrees or $10^{2} \mathrm{~km}$ ), which lessens their ability 
to capture spatial details in climate patterns that are often required or desired in regional or local analysis and (b) the local statistical biased characteristics (i.e., mean, variance, etc.) when compared with observations [77].

Because of the reliability and high spatial resolution provided by the NEX-GDDP, it is very convenient to perform climate projections analysis while using this dataset to evaluate the impacts of climate change on rainfall distribution in Costa Rica. The intraseasonal, seasonal, and annual cycle long-term changes projected in precipitation and DTR in Costa Rica at the end of the twenty-first century were computed while using the differences between the multimodel ensembles of the two prospective scenarios corresponding to the RCP 4.5 and 8.5 for the period of 2070-2099 and the retrospective scenario for the baseline period of 1970-1999 [82]. The multimodel ensemble mean of precipitation and DTR studied in this research were computed while using the following equation:

$$
\langle x\rangle=\frac{1}{n} \sum_{i=1}^{i=n} x_{i}
$$

where \langle\rangle is the ensemble, $x$ is the ensemble member variable, and $n$ is given by the number of total ensemble members $(n=1, \ldots, 21)$.

In order to detect the ensemble atypical values we used an outliers detection algorithm that is based on the probabilistic approach described by Wilcox [83], where a value is declared as atypical if the absolute value of the difference between this one and the ensemble exceeds two standard deviations $(2 \sigma)$, as shown in Equation (3).

$$
|x-\langle x\rangle|>2 \sigma
$$

Central America and the Caribbean domain $\left(5-25^{\circ} \mathrm{N}, 95-60^{\circ} \mathrm{W}\right)$ was selected in order to analyze the annual and boreal seasonal (summer (JJA) and winter (DJF)) multimodel ensemble mean long-term changes. The climate change impact assessment on annual distribution of precipitation and DTR was performed over five regions of analysis. The first region covers the entire Costa Rican territory (Costa Rica Continental), the second comprises the region from the Caribbean coast to the central mountain range (Caribbean Watershed), the third one covers the Pacific coast to the central mountain range (Pacific Watershed), the fourth only considers the North Pacific region (a.k.a Chorotega Region; the most arid area of Costa Rica, [67]), and the fifth takes the rest of the Pacific (South and Central Pacific Region) into account.

\subsection{Surface Meteorological Stations}

Rainfall from six and temperature from five surface meteorological stations for the retrospective baseline scenario (1970-1999) were selected in order to perform multimodel data assessments. The surface stations were selected as representative of the Pacific Watershed, namely: La Guinea (also in the Chorotega Region), Juan Santamaría, Fabio Baudrit, Rancho Redondo, and Piñera (located in southwestern Costa Rica, it was added to the analysis to separate this region from the northwest), and one as representative of the Caribbean Watershed, namely: Limón. Figure 1 shows the meteorological stations distribution across the country and Table 3 summarizes the metadata and their climatological (1970-1999) basics data (average, maximum, and minimum precipitation, and DTR) of the stations when comparing to the NEX-GDDP multimodel ensemble.

In Costa Rica, as in most Central America countries, past meteorological data have not been treated extensively to generate observed long term reliable data bases. During the last 2-3 decades, national meteorological services and some international institutions (i.e., CHIRPS, https:/ / www.chc. ucsb.edu/data/chirps) have made efforts to gather and generate past weather and climate information and, although the situation has improved, not all data have undergone quality and homogeneity tests. Uncertainties in gridded meteorological datasets, such as CHIRPS, are also sources of error for these types of works [63]. For this work, the initial space and time coverage of observed data were deficient, 
so, authors performed quality control and testing on available information to complete the station data used here. As pointed out by Hidalgo et al. [63], there is a need for data to do research on climate variability and change in the region, especially with current limitations in the availability and quality of data. Recently, Amador et al. [84] also stressed the difficulties to gather both original historical documents and instrumental data for past climate studies.

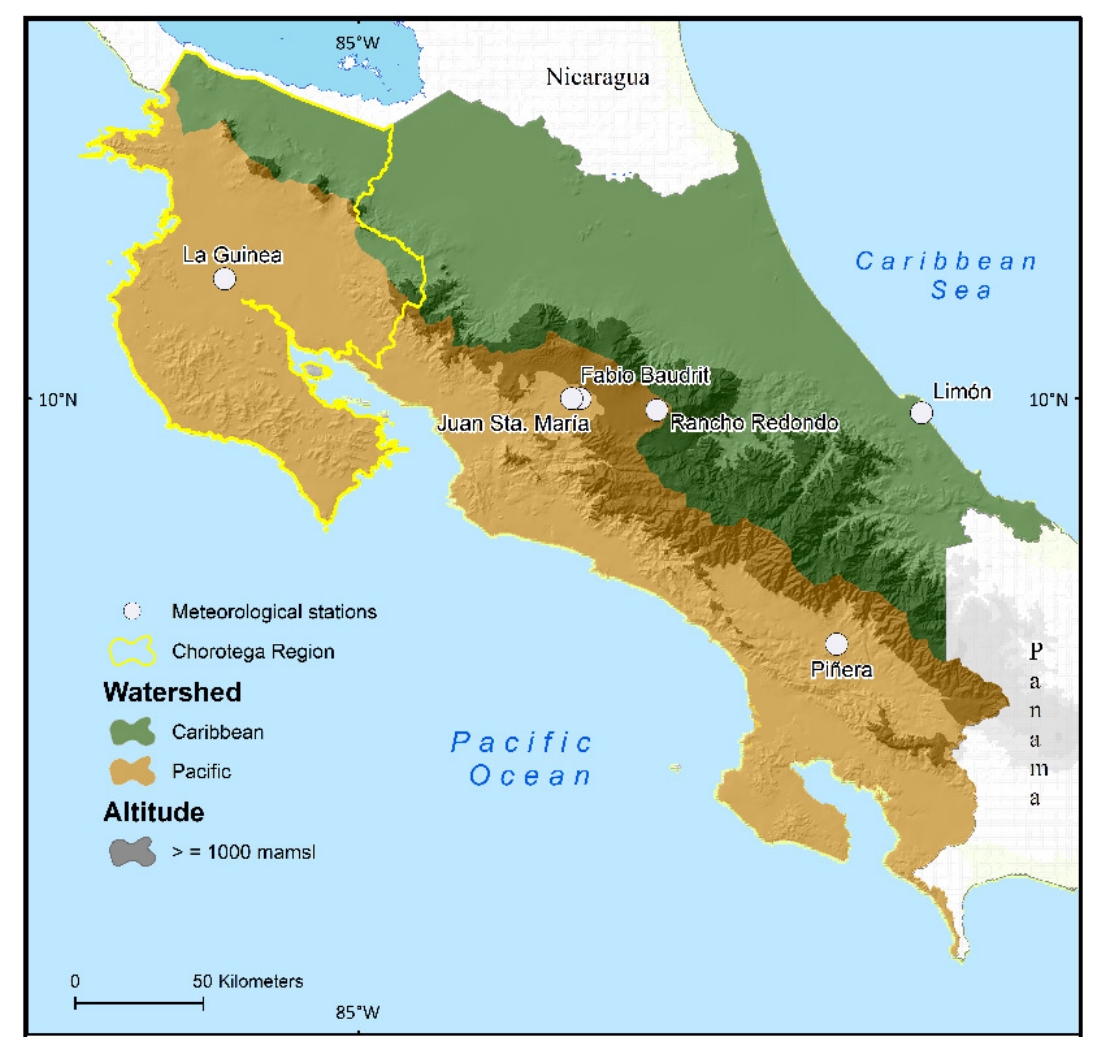

Figure 1. Location map of surface meteorological stations over Costa Rica. Digital elevation model from Ortiz-Malavasi [85].

Table 3. Meteorological stations metadata and their climatological (1970-1999) basics data. A: Altitude (m), Lat: Latitude (N), Lon: Longitude (W), $\operatorname{Pr}(\mathrm{mm} / \mathrm{month}), \operatorname{DTR}\left({ }^{\circ} \mathrm{C}\right), \mathrm{O}$ : Observation, and M: Model.

\begin{tabular}{|c|c|c|c|c|c|c|c|c|c|c|c|c|c|c|c|}
\hline \multirow[b]{2}{*}{ Station } & \multirow[b]{2}{*}{$\mathbf{A}$} & \multirow[b]{2}{*}{ Lat } & \multirow[b]{2}{*}{ Lon } & \multicolumn{2}{|c|}{$P r_{m e a n}$} & \multicolumn{2}{|c|}{$P r_{\text {max }}$} & \multicolumn{2}{|c|}{$P r_{\min }$} & \multicolumn{2}{|c|}{$D T R_{\text {mean }}$} & \multicolumn{2}{|c|}{$D T R_{\max }$} & \multicolumn{2}{|c|}{$D T R_{\min }$} \\
\hline & & & & $O$ & $M$ & $O$ & $M$ & $O$ & $M$ & $O$ & $M$ & $O$ & $M$ & $O$ & $M$ \\
\hline Limón & 4 & 9.95 & 83.02 & 297.35 & 253.29 & 461.66 & 350.82 & 178.78 & 152.48 & 8.06 & 10.30 & 8.67 & 11.92 & 7.24 & 9.24 \\
\hline La Guinea & 75 & 10.42 & 85.47 & 144.06 & 149.74 & 335.60 & 353.43 & 2.94 & 3.03 & 10.36 & 11.55 & 12.51 & 13.42 & 8.76 & 10.36 \\
\hline Fabio Baudrit & 845 & 10.00 & 84.25 & 165.53 & 241.30 & 340.86 & 412.27 & 11.40 & 67.70 & 10.67 & 11.10 & 12.58 & 13.10 & 9.49 & 9.89 \\
\hline Rancho Redondo & 2028 & 9.96 & 83.95 & 209.55 & 328.68 & 435.38 & 487.50 & 18.26 & 149.99 & 9.50 & 11.10 & 11.42 & 13.12 & 8.30 & 9.93 \\
\hline Piñera & 350 & 9.14 & 83.32 & 289.86 & 248.86 & 561.53 & 510.45 & 32.45 & 42.72 & - & - & - & - & - & - \\
\hline
\end{tabular}

\section{Results}

\subsection{Data Assessment Evaluation}

From Table 3, the ability of the BCSD algorithm to adjust the precipitation data close to that of La Guinea station is noteworthy. Additionally, in the cases of Juan Santamaría, Fabio Baudrit, and Rancho Redondo stations as compared to the NEX-GDDP data, it can be seen precipitation overestimation. In the case to $D T R$, an overestimation also exists in all stations; however, the smallest overestimation is close to that of Fabio Baudrit station.

Figure 2 shows the monthly multimodel ensemble distributions for historical NEX-GDDP precipitation and DTR for the period 1970-1999 as compared to six surface meteorological stations 
data (column A and C, respectively, see Figure 1 for stations data location). All stations, except Limón in the Caribbean, present similar observed annual rainfall distributions; however, what makes them different is the intensity of the rainfall totals in June and September-October and the MSD minimum, as defined by Maldonado et al. [21]. This is a crucial factor, for agriculture, tourism, and other economic sectors that the NEX-GDDP data are not capturing. Moreover, model data are not able to reproduce the MSD in any sense, except in northwestern and southwestern Pacific, presenting a feature in August that is not observed in the surface data in Fabio Baudrit and Juan Santamaría stations, confirming the shortcomings of the NEX-GDDP data. Differences between NEX-GDDP information and observed data may be due to the lack of ability of the model parameterization schemes to deal with mountainous regions at the $0.25^{\circ} \times 0.25^{\circ}$ horizontal resolution. For the DTR, it can be observed that the NEX-GDDP data adequately captured the pattern of the annual cycle in all five stations, however, an overestimation of that cycle is also exhibited by NEX-GDDP being more remarkable in the Limón station. A consequence that results from this analysis is that the results that are associated with the Chorotega Region and the Pacific Watershed are more reliable than those related to the Caribbean Watershed. This limitation was identified by Hidalgo and Alfaro [86], and it is possibly associated with the lack of ability of current climate models to simulate the poor current knowledge of processes driving the MSD and its evolution. Future changes in the tropical circulations (i.e., fluctuations in the trade winds intensity and strength of the CLLJ and SSTs) under climate change are likely to be another cause for this discrepancy [87-89].

\subsection{Rainfall}

Figure 3 shows the multimodel ensemble mean projected changes in precipitation for RCP 4.5 and 8.5 scenarios over Central America and the Caribbean. The results show a reduction of rainfall over most of the domain, mainly in Central America (except for Panama), and the Greater and Lesser Antilles. The rainfall decrease seems to be more important during boreal summer for the RCP 8.5 scenario. This could be related to a future differential warming in the Pacific and Atlantic Oceans [90], where the projected rainfall deficit over Central America and the surplus in the Pacific coastal regions of northern South America could be associated with the potential intensification of ENSO and SST increase linked to future warming [91].

These results are in agreement with Hidalgo et al. [63], for projected climate in the 2050-2099 period that showed a decrease in precipitation (as much as 5-10\%) in northern Central America. Similarly, Maurer et al. [65] reported a projected enlargement in the MSD length by an average of approximately a week and a decrease in its precipitation minimum by nearly $26 \%$ and a decline of $9.6 \%$ in annual total precipitation within the RCP 8.5 scenario for most of Nicaragua, Honduras, El Salvador, and Guatemala. The projected precipitation drop is a potential threat in terms of severe water stress affecting the water resources supply (for both consumption and agriculture) and hydroelectric power generation over this region.

Table 4 shows the precipitation trends ( $\mathrm{mm} /$ decade) over Costa Rica different regions from 1950-2100 while using the Mann-Kendall test at the 95\% confidence level [83]. It can be seen that all regions have negative significant statistical trends, but Caribbean Watershed and Chorotega Region have the higher significant statistical trends.

Figure 4 presents monthly multimodel ensemble distributions for historical NEX-GDDP precipitation for the period 1970-1999 (column A), and their corresponding future changes for the period 2070-2099 for RCP 4.5 and 8.5 scenarios (column B), for Costa Rica different regions (column E). It should be noted that precipitation changes indicate an early onset of the rainy season for Costa Rica (signal found in all country's different regions), projecting rainfall increasing in the transition season from a dry to a rainier season (March to April). Additionally, a small rainfall increase (decrease) is projected in the RCP 8.5 (RCP 4.5) scenario in the transition month from rainy to dry conditions (November) over all different regions (just in Caribbean Watershed and Chorotega Region). 
Precipitation during the rainy season (May to October) and the minimum of the MSD are projected to decline.

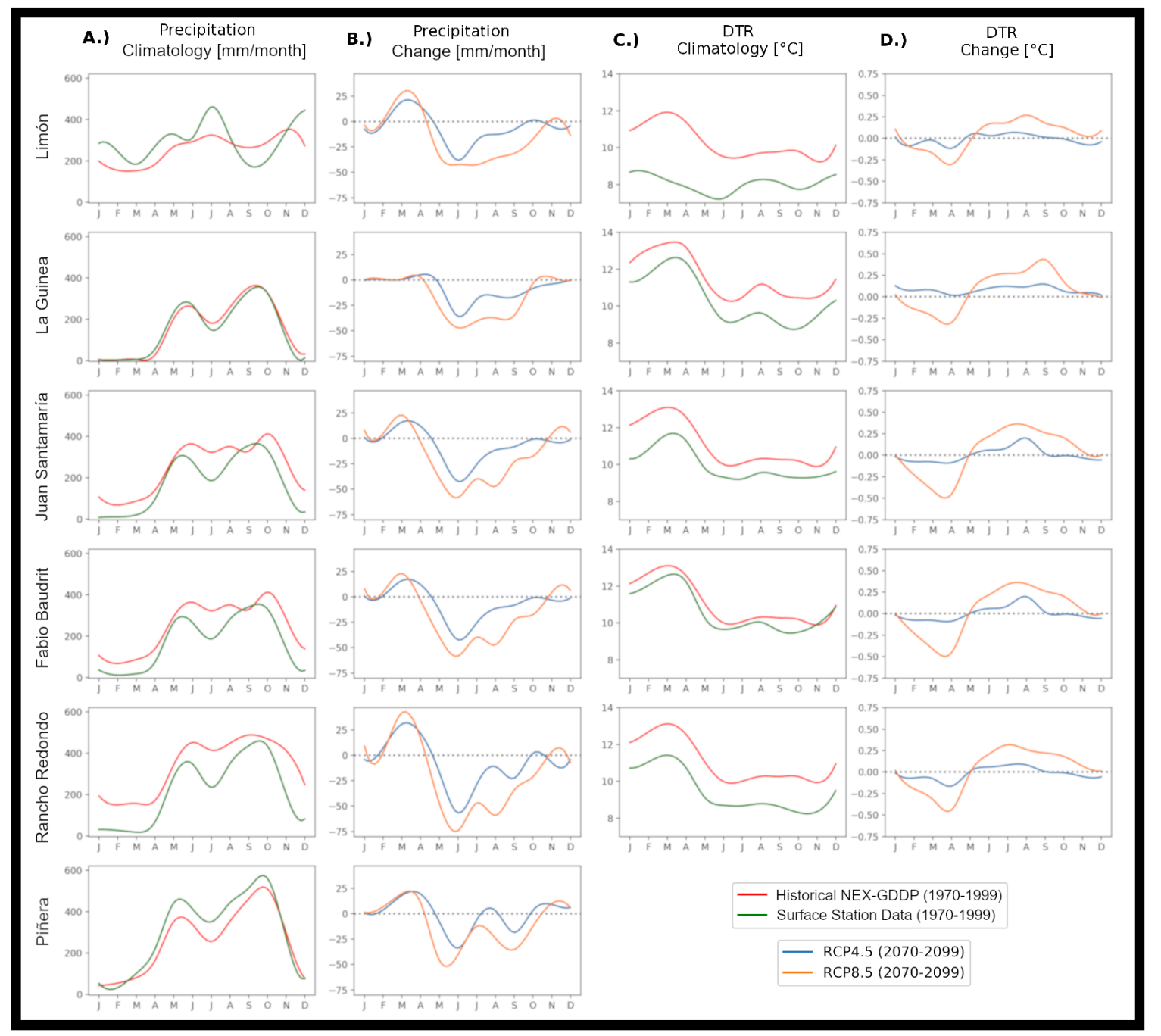

Figure 2. CMIP5 Monthly Multimodel Ensemble distributions for historical NEX-GDDP precipitation and diurnal temperature range (DTR) for the period 1970-1999 as compared to different surface station data (column (A) and (C), respectively), and their corresponding future changes for the period 2070-2099 for RCP 4.5 and 8.5 scenarios (column (B) and (D), respectively). See Figure 1 for station data location.

Table 4. Precipitation (mm/decade) and $D T R\left(\mathrm{~m}^{\circ} \mathrm{C} /\right.$ decade) trends over Costa Rica different regions from 1950-2100 using the Mann-Kendall test at the 95\% confidence level.

\begin{tabular}{lcccc}
\hline & \multicolumn{2}{c}{ Precipitation } & \multicolumn{2}{c}{ DTR } \\
\cline { 2 - 5 } & RCP 4.5 & RCP 8.5 & RCP 4.5 & RCP 8.5 \\
\hline Costa Rica Continental & -16.74 & -27.51 & - & - \\
Caribbean Watershed & -21.60 & -34.02 & - & 4.6 \\
Pacific Watershed & -14.74 & -26.92 & - & - \\
Chorotega Region & -19.20 & -32.56 & 5.7 & - \\
South \& Central Pacific Region & -10.20 & -19.98 & 3.4 & - \\
\hline
\end{tabular}




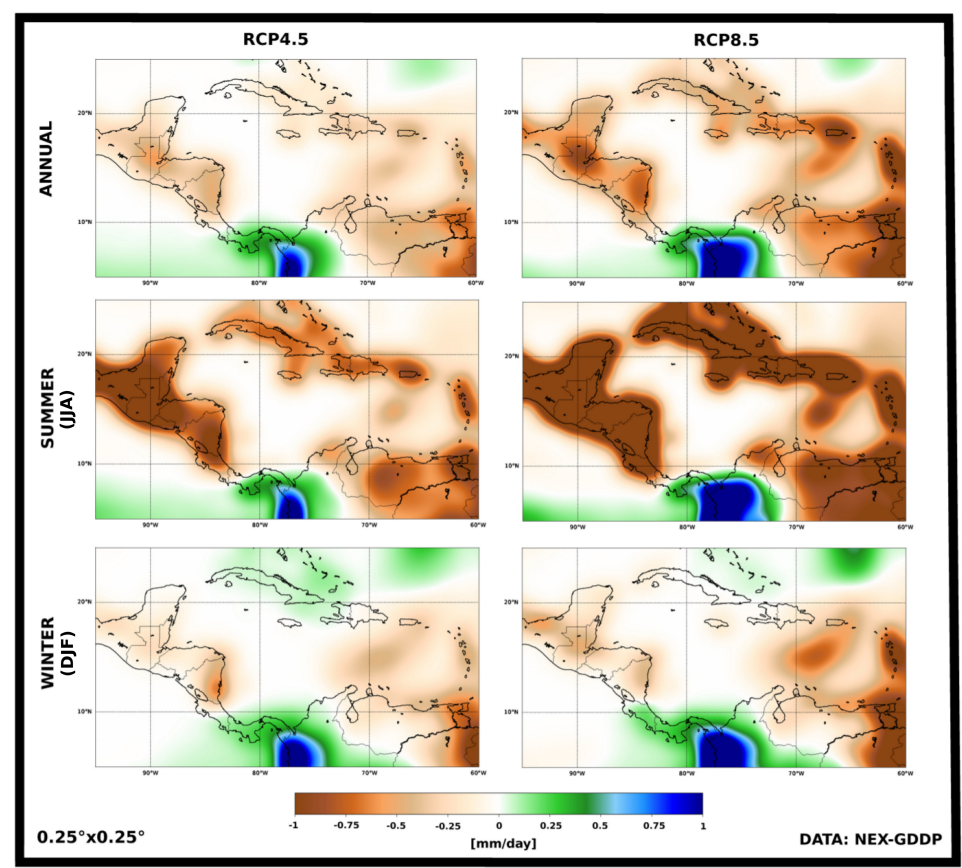

Figure 3. CMIP5 Multimodel Ensemble Mean change in precipitation (mm/day) for 2070-2099 minus 1970-1999 for RCP 4.5 and 8.5 scenarios.

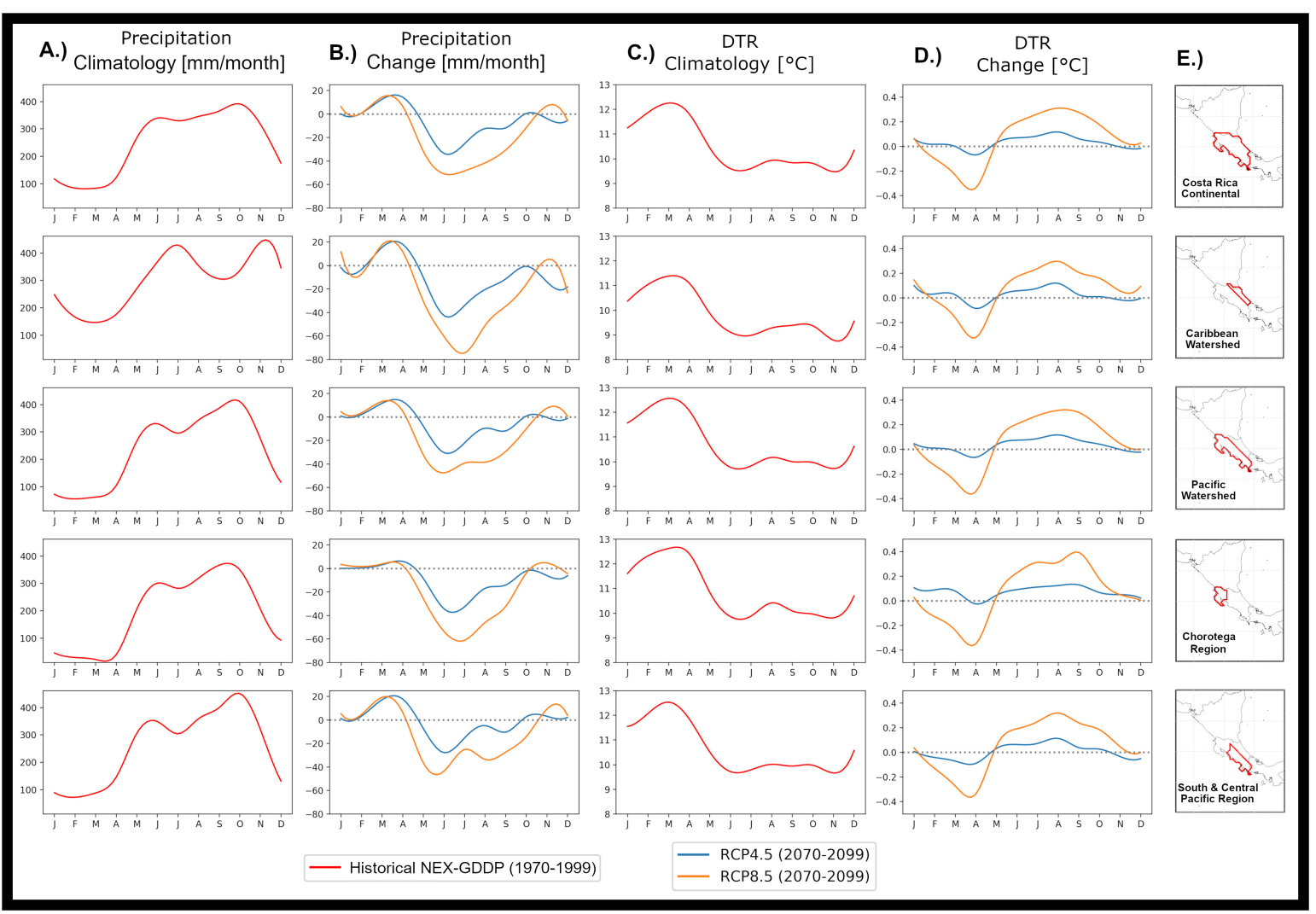

Figure 4. CMIP5 Monthly Multimodel Ensemble distributions for historical NEX-GDDP precipitation and diurnal temperature range (DTR) for the period 1970-1999 (column (A) and (C), respectively), and their corresponding future changes for the period 2070-2099 for RCP 4.5 and 8.5 scenarios (column (B) and (D), respectively), over Costa Rica different regions (column (E)). 
Figure 2 in a like manner shows the monthly multimodel ensemble distributions for historical NEX-GDDP precipitation (column A) and their corresponding future changes (column B). It can be observed that the distributions follow the same patterns that are shown in Figure 4; however, in this figure more details are exhibited.

\subsection{Temperature}

Despite that a majority of climate projections tend to focus on the changes in mean temperature or temperature extremes, here we focus on the DTR instead, as it has been shown that ecosystems are more sensitive to the thermal amplitude of the environment $[92,93]$. Figure 5 shows the projected multimodel ensemble mean changes in DTR for RCP 4.5 and 8.5 scenarios over Central America and the Caribbean. It can be noticed that $D T R$ and precipitation changes exhibit an opposite behavior, $D T R$ decreases, while precipitation increases and vice versa. Even though causality is not directly implied, it should be considered that the variations in the availability of moisture due to rainfall changes is expected to have a local impact over surface temperature. A local reduction in rainfall affects humidity, as plants may increase transpiration due to water stress, with the latter being a highly relevant constraint for most ecosystems. Under such conditions in densely forested areas, via transpiration, water vapor is transferred to the atmosphere increasing the capacity of the air above the canopy to warm up. Furthermore, DTR variations imply that temperature extremes are changing, which is relevant according to the Clausius-Clapeyron relationship, saturation vapor pressure increases by approximately $7 \%$ per ${ }^{\circ} \mathrm{C}$ of warming [94]. As a result, warming would affect saturation and as a result, the potential for evapotranspiration is also affected, which at the same time impinges an impact on the surface-atmosphere feedback within the hydrological cycle. In addition, there are species that need specific temperature extremes for their functioning and, as DTR decreases, such species become endangered at a faster rate.

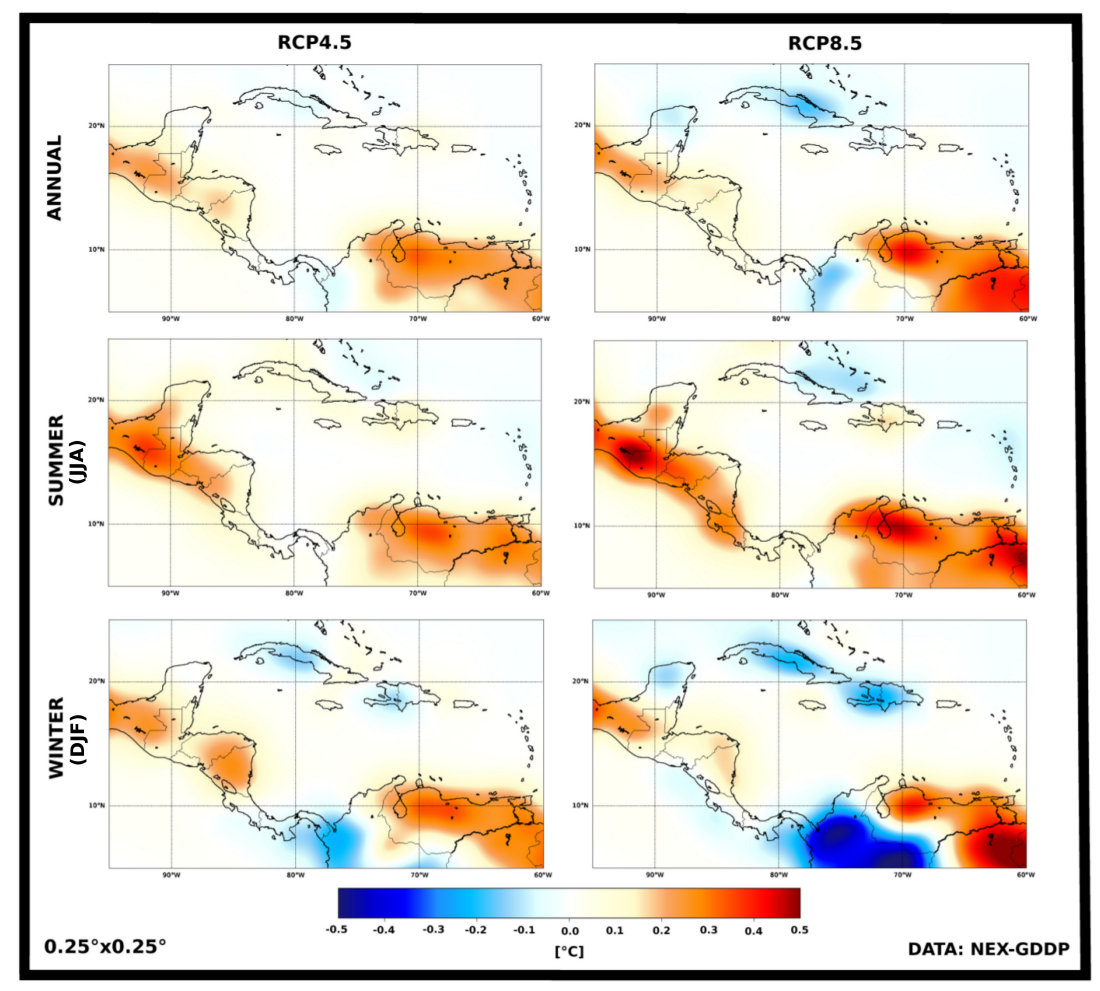

Figure 5. CMIP5 Multimodel Ensemble Mean change in DTR $\left({ }^{\circ} \mathrm{C}\right)$ for 2070-2099 minus 1970-1999 for RCP 4.5 and 8.5 scenarios.

The monthly multimodel ensemble distributions for DTR are presented in Figure 4 (column $\mathrm{C}$ for baseline and column D for future changes) over Costa Rica different regions (column E) and 
locally in Figure 2 (column C for baseline and column D for future changes). As we mentioned before, DTR change projections are opposite to future precipitation change. Finally, it was found that, in most of Costa Rica regions, there are no significant statistical trends $\left(\mathrm{m}^{\circ} \mathrm{C} /\right.$ decade) for DTR based on the Mann-Kendall test at the 95\% confidence level. Only Chorotega Region and South and Central Pacific Region for RCP 4.5 and Caribbean Watershed for RCP 8.5 showing significant statistical trends (see Table 4). It can be observed that projected DTR changes and their trends have very small magnitudes $\left(\sim 10^{-1}\right.$ and $\sim 10^{-3} /$ decade, respectively). This is because the maximum and minimum temperatures are projected to increase in a very similar future rate in Costa Rica.

\section{Conclusions}

This work suggests that Costa Rica is an inflexion region for climate change impacts in Central America, because the projected precipitation decreases in Costa Rica until Guatemala and it increases in Panama. This result agrees with Hidalgo et al. [63,64] and Maurer et al. [65], whose studies projected significant reductions in precipitation in northern Central America.

We find that $D T R$ changes are opposite to future precipitation change. The very small magnitudes of projected $D T R$ changes and their trends suggest that the maximum and minimum temperatures are projected to increase in a very similar future rate in Costa Rica.

Additionally, the precipitation changes indicate an early onset of the rainy season for Costa Rica, since the projected rainfall increases during the transition period from the dry to rainy season (March to April). Additionally, the precipitation during the rainy season (May to October) and the minimum of the MSD are projected to decline. The results that are associated with the Chorotega Region and the Pacific Watershed are more reliable than those associated with the Caribbean Watershed. This is because the NEX-GDDP data could not reproduce the rainfall features particularities in all Costa Rica different regions. This may be a limitation of this dataset and a more realistic downscaled model might be needed.

The authors recognized the shortcomings in the availability of station data to assess past and future model results in this research; however, as has been noted by other works, this has also been a major regional limitation in clarifying the uncertainty of future climate projections $[63-65,67]$. Despite this limitation with the station data used, it is still possible to draw some conclusions regarding future climate in some regions of Costa Rica, especially in the northwest side of the country, where past data are consistent with model information, providing a more reliable picture of changes in climate there that has potential implications for socioeconomic sectors.

The results that are presented herein are to be implemented, as part of a set of tools devoted to supporting decision-making, for both territory planning as well as in relation to economic activities, such as those that are related to agriculture, tourism, food security, and hydroelectric power generation. These contributions become highly relevant for areas that are identified as those becoming dryer than the current climate and whose economies and livelihood are largely dependent on rainfall.

Author Contributions: Conceptualisation was developed by R.C. and J.A.A.; data preparation and results were carried out by R.C.; writing was performed by R.C.; review and editing by R.C. and J.A.A. All authors have read and agreed to the published version of the manuscript.

Funding: The authors wish to acknowledge the funding of this research through the following Vicerrectoría de Investigación, Universidad de Costa Rica grants: V.I. 805-C0-074, B6-147 (Fondo Ordinario), B9-609, B7-605 (Fondo de Estímulo), B9-454 (Grupos de Investigación) and B8-766 (Redes Temáticas).

Acknowledgments: This research is supported by the University of Costa Rica (UCR) and the computational support is provided by the Center of Geophysical Research (CIGEFI). The supports are gratefully acknowledged. We also kindly acknowledge Juan Carlos Badilla Rojas who did some figures for this research. Also, we thank National Meteorological Institute (IMN) of Costa Rica for providing their surface weather stations records, which they were used as input for this research. Finally we sincerely thank Ana María Durán Quesada for her comments, which have improved the manuscript.

Conflicts of Interest: The authors declare no conflict of interest. 


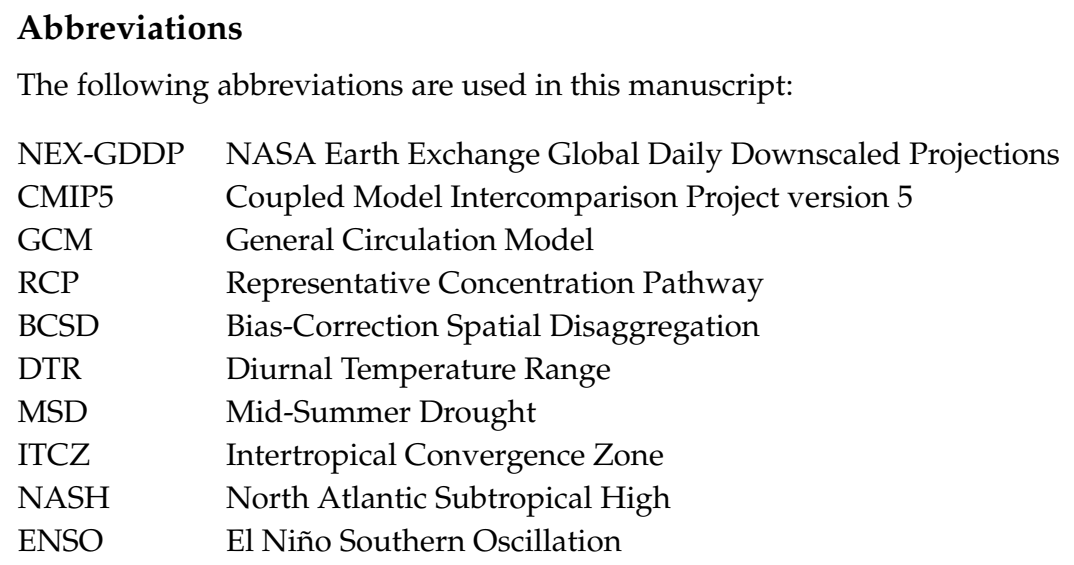

\section{References}

1. Hall, C. América central como región geográfica. In Anuario de Estudios Centroamericanos; Universidad de Costa Rica: San José, Costa Rica, 1985; pp. 5-24,

2. Mittermeier, R.A.; Myers, N.; Thomsen, J.B.; Da Fonseca, G.A.; Olivieri, S. Biodiversity hotspots and major tropical wilderness areas: Approaches to setting conservation priorities. Conserv. Biol. 1998, 12, 516-520. [CrossRef]

3. Pagiola, S. Payments for environmental services in costa rica. Ecol. Econ. 2008, 65, 712-724. [CrossRef]

4. Pagiola, S.; Agostini, P.; Gobbi, J.; de Haan, C.; Ibrahim, M.; Murgueitio, E.; Ramírez, E.; Rosales, M.; Ruíz, J.P. Paying for biodiversity conservation services: Experience in colombia, costa rica, and nicaragua. Mt. Res. Dev. 2005, 25, 206-211. [CrossRef]

5. Zbinden, S.; Lee, D.R. Paying for environmental services: An analysis of participation in costa rica's psa program. World Dev. 2005, 33, 255-272. [CrossRef]

6. Harvey, C.A.; Komar, O.; Chazdon, R.; Ferguson, B.G.; Finegan, B.; Griffith, D.M.; Martínez-Ramos, M.; Morales, H.; Nigh, R.; Soto-Pinto, L.; et al. Integrating agricultural landscapes with biodiversity conservation in the mesoamerican hotspot. Conserv. Biol. 2008, 22, 8-15. [CrossRef]

7. Kosoy, N.; Martinez-Tuna, M.; Muradian, R.; Martinez-Alier, J. Payments for environmental services in watersheds: Insights from a comparative study of three cases in central america. Ecol. Econ. 2007, 61, 446-455. [CrossRef]

8. Andam, K.S.; Ferraro, P.J.; Sims, K.R.; Healy, A.; Holland, M.B. Protected areas reduced poverty in costa rica and thailand. Proc. Natl. Acad. Sci. USA 2010, 107, 9996-10001. [CrossRef] [PubMed]

9. Kowollik, M. Costa Rica Carbono Neutral: un País Pequeño con Metas Grandes; PERSPECTIVAS FES Costa Rica; Fundación Friedrich Ebert: San José, Costa Rica, 2014.

10. Hastenrath, S.L. Rainfall distribution and regime in central america. Arch. Meteorol. Geophys. Bioklimatol. Ser. B 1967, 15, 201-241. [CrossRef]

11. Vargas, G. Las lluvias en américa central: Una climatología geográfica. In Anuario de Estudios Centroamericanos; Universidad de Costa Rica: San José, Costa Rica, 2001; pp. 7-19.

12. Vargas, G. La escala zonal, regional y local en el análisis del régimen pluviométrico del istmo centroamericano. Reflexiones 2004, 83, 4 .

13. Alfaro, E.J.; Cid, L. Análisis de las anomalías en el inicio y el término de la estación lluviosa en centroamérica y su relación con los océanos pacífico y atlántico tropical. Tóp. Meteorol. Ocean. 1999, 6, 1-13.

14. Alfaro, E.J. Response of air surface temperatures over central america to oceanic climate variability indices. Tóp. Meteorol. Ocean. 2000, 7, 63-72. [CrossRef]

15. Alfaro, E.J. Some characteristics of the annual precipitation cycle in central america and their relationships with its surrounding tropical oceans. Tóp. Meteorol. Ocean. 2002, 9, 88-103.

16. Alfaro, E.J.; Chourio, X.; Muñoz, Á.G.; Mason, S.J. Improved seasonal prediction skill of rainfall for the primera season in central america. Int. J. Climatol. 2018, 38, e255-e268. [CrossRef]

17. Mosiño, A.P.; García, E. Evaluación de la sequía intraestival en la república mexicana. Proc. Conf. Reg. Latinoam. Unión Geogr. Int. 1966, 3, 500-516.

18. Coen, E. El floklore costarricense relativo al clima. Rev. Univ. Costa Rica 1973, 35, 135-145. 
19. Magaña, V.; Amador, J.A.; Medina, S. The midsummer drought over mexico and central america. J. Clim. 1999, 12, 1577-1588. [CrossRef]

20. Karnauskas, K.B.; Seager, R.; Giannini, A.; Busalacchi, A.J. A simple mechanism for the climatological midsummer drought along the pacific coast of central america. Atmósfera 2013, 26, 261-281. [CrossRef]

21. Maldonado, T.; Rutgersson, A.; Alfaro, E.; Amador, J.; Claremar, B. Interannual variability of the midsummer drought in central america and the connection with sea surface temperatures. Adv. Geosci. 2016, 42, 35-50. [CrossRef]

22. Amador, J.A. A climatic feature of the tropical americas: The trade wind easterly jet. Tóp. Meteorol. Ocean. 1998, 5, 1-13.

23. Amador, J.A. The intra-americas sea low-level jet. Ann. N. Y. Acad. Sci. 2008, 1146, 153-188. [CrossRef]

24. Sáenz, F.; Amador, J.A. Características del ciclo diurno de precipitación en el Caribe de Costa Rica. Rev. Climatol. 2016, 6, 21-34.

25. Taylor, M.A.; Alfaro, E.J. Climate of central america and the caribbean. In Encyclopedia of World Climatology; Springer: Dordrecht, The Netherlands, 2005; pp. 183-189.

26. Amador, J.A.; Alfaro, E.J.; Lizano, O.G.; Magaña, V.O. Atmospheric forcing of the eastern tropical pacific: A review. Prog. Oceanogr. 2006, 69, 101-142. [CrossRef]

27. Amador, J.A.; Durán-Quesada, A.; Rivera, E.; Mora, G.; Sáenz, F.; Calderón, B.; Mora, N. The easternmost tropical pacific. part II: Seasonal and intraseasonal modes of atmospheric variability. Rev. Biol. Trop. 2016, 64 (Suppl. 1), S23-S57. [CrossRef]

28. Hidalgo, H.G.; Durán-Quesada, A.M.; Amador, J.A.; Alfaro, E.J. The caribbean low-level jet, the inter-tropical convergence zone and precipitation patterns in the intra-americas sea: A proposed dynamical mechanism. Geogr. Ann. Ser. A Phys. Geogr. 2015, 97, 41-59. [CrossRef]

29. Quirós, E.; Hidalgo, H.G. Variabilidad y conexiones climáticas de la zona de convergencia intertropical del pacífico este. Tóp. Meteorol. Ocean. 2016, 15, 21-36.

30. Quirós, E.; Hidalgo, H.G. Interacción de la zona de convergencia intertropical del pacíico este con sistemas tropicales. Tóp. Meteorol. Ocean. 2016, 15, 33-47.

31. Zárate-Hernández, E. Climatología de masas invernales de aire frío que alcanzan centroamérica y el caribe y su relación con algunos índices árticos. Tóp. Meteorol. Ocean. 2013, 12, 35-55.

32. Zárate-Hernández, E. Influencia de las masas invernales de aire frío sobre el chorro de bajo nivel del caribe y sus ramas. Tóp. Meteorol. Ocean. 2014, 13, 19-40.

33. Chinchilla, G.; Gutiérrez, J.; Zárate, E. Eventos extremos de lluvia ocasionados por empujes fríos que han llegado a costa rica en el periodo invernal (ndef) del año 2000 al 2010: Líneas de cortante. Tóp. Meteorol. Ocean. 2016, 15, 48-62.

34. Chinchilla, G.; Gutiérrez, J.; Zárate, E. Análisis sinóptico de casos de eventos extremos de lluvia asociados a líneas de cortante de empujes fríos que han llegado a costa rica en el periodo invernal. Tóp. Meteorol. Ocean. 2017, 16, 48-62.

35. Amador, J.A.; Alfaro, E.J.; Rivera, E.R.; Calderón, B. Climatic features and their relationship with tropical cyclones over the intra-americas seas. In Hurricanes and Climate Change; Springer: Dordrecht, The Netherlands, 2010; pp. 149-173.

36. Mosiño, P.; García, E. Rainfall analysis in méxico and central américa. Rev. Geogr. 1972, 10, $43-64$.

37. Maldonado, T.; Alfaro, E.; Rutgersson, A.; Amador, J.A. The early rainy season in central america: The role of the tropical north atlantic ssts. Int. J. Climatol. 2017, 37, 3731-3742. [CrossRef]

38. Amador, J.A.; Alfaro, E. La oscilación cuasi-bienal, enos y acoplamiento de algunos parámetros superficiales y estratosféricos sobre costa rica. Tóp. Meteorol. Ocean. 1996, 3, 45-54.

39. Fujiwara, M.; Vömel, H.; Hasebe, F.; Shiotani, M.; Ogino, S.-Y.; Iwasaki, S.; Nishi, N.; Shibata, T.; Shimizu, K.; Nishimoto, E.; et al. Seasonal to decadal variations of water vapor in the tropical lower stratosphere observed with balloon-borne cryogenic frost point hygrometers. J. Geophys. Res. Atmos. 2010, 115, D18304. [CrossRef]

40. Barlow, M.; Salstein, D. Summertime influence of the madden-julian oscillation on daily rainfall over mexico and central america. Geophys. Res. Lett. 2006, 33, L21708. [CrossRef]

41. Poleo-Brito, D.; Solano León, E.; Stolz España, W. La oscilación madden-julian y las precipitationes extremas en costa rica. Tóp. Meteorol. Ocean. 2014, 13, 5-18.

42. Poleo-Brito, D.; Solano León, E.; Stolz España, W. La oscilación atmosférica madden-julian (mjo) y las lluvias en costa rica. Tóp. Meteorol. Ocean. 2014, 13, 58-74. 
43. Durán-Quesada, A.M.; Gimeno, L.; Amador, J.; Nieto, R. Moisture sources for central america: Identification of moisture sources using a lagrangian analysis technique. J. Geophys. Res. Atmos. 2010, 115, D05103. [CrossRef]

44. Durán-Quesada, A.M.; Gimeno, L.; Amador, J. Role of moisture transport for central american precipitation. Earth Syst. Dyn. 2017, 8, 147-161. [CrossRef]

45. Castillo, R.; Nieto, R.; Gimeno, L.; Drumond, A. Influencia de los principales modos anulares hemisféricos y el niño-oscilación del sur (enos) en las fuentes de humedad globales de mesoamérica. Rev. Acad. Colomb. Cienc. Exactas Físicas Nat. 2019, 43, 746-763. [CrossRef]

46. Krishnan, R.; Sanjay, J.; Gnanaseelan, C.; Mujumdar, M.; Kulkarni, A.; Chakraborty, S. Assessment of Climate Change over the Indian Region: A Report of the Ministry of Earth Sciences (MoES), Government of India. Springer Nat. 2020, 226. [CrossRef]

47. Li, Y.; Chen, Y.; Wang, F.; He, Y.; Li, Z. Evaluation and projection of snowfall changes in High Mountain Asia based on NASA's NEX-GDDP high-resolution daily downscaled dataset. Environ. Res. Lett. 2020, 15, 104040. [CrossRef]

48. Lin, Q.; Wang, Y.; Glade, T.; Zhang, J.; Zhang, Y. Assessing the spatiotemporal impact of climate change on event rainfall characteristics influencing landslide occurrences based on multiple GCM projections in China. Clim. Chang. 2020, 162, 761-779. [CrossRef]

49. Liu, B.; Lund, J.R.; Liu, L.; Liao, S.; Li, G.; Cheng, C. Climate Change Impacts on Hydropower in Yunnan, China. Water 2020, 12, 197. [CrossRef]

50. Ran, H.; Li, J.; Zhou, Z.; Zhang, C.; Tang, C.; Yu, Y. Predicting the spatiotemporal characteristics of flash droughts with downscaled CMIP5 models in the Jinghe River basin of China. Environ. Sci. Pollut. Res. 2020, 27, 40370-40382. [CrossRef]

51. Wang, J.; Feng, J.; Yan, Z.; Chen, Y. Future risks of unprecedented compound heat waves over three vast urban agglomerations in China. Earth's Future 2020, 8, e2020EF001716. [CrossRef]

52. Wu, Y.; Miao, C.; Duan, Q.; Shen, C.; Fan, X. Evaluation and projection of daily maximum and minimum temperatures over China using the high-resolution NEX-GDDP dataset. Clim. Dyn. 2020, 55, 2615-2629. [CrossRef]

53. Abiodun, B.J.; Mogebisa, T.O.; Petja, B.;Abatan, A.A.; Roland, T.R. Potential impacts of specific global warming levels on extreme rainfall events over southern Africa in CORDEX and NEX-GDDP ensembles. Int. J. Climatol. 2020, 40, 3118-3141. [CrossRef]

54. Ndhlovu, G.Z.; Woyessa, Y.E. Modelling impact of climate change on catchment water balance, Kabompo River in Zambezi River Basin. J. Hydrol. Reg. Stud. 2020, 27, 100650. [CrossRef]

55. Gutierrez, A.P.; Ponti, L.; Arias, P.A. Deconstructing the eradication of new world screwworm in North America: Retrospective analysis and climate warming effects. Med. Vet. Entomol. 2019, 33, 282-295. [CrossRef]

56. Iwamura, T.; Guzman-Holst, A.; Murray, K.A. Accelerating invasion potential of disease vector Aedes aegypti under climate change. Nat. Commun. 2020, 11, 1-10. [CrossRef] [PubMed]

57. Avila-Diaz, A.; Abrahão, G.; Justino, F.; Torres, R.; Wilson, A. Extreme climate indices in Brazil: Evaluation of downscaled earth system models at high horizontal resolution. Clim. Dyn. 2020, 54, 5065-5088. [CrossRef]

58. Vigliano, P.H.; Rechencq, M.M.; Fernández, M.V.; Lippolt, G.E.; Macchi, P.J. Fish thermal habitat current use and simulation of thermal habitat availability in lakes of the Argentine Patagonian Andes under climate change scenarios RCP 4.5 and RCP 8.5. Sci. Total Environ. 2018, 636, 688-698. [CrossRef] [PubMed]

59. Giorgi, F. Climate change hot-spots. Geophys. Res. Lett. 2006, 33, L08707. [CrossRef]

60. Diffenbaugh, N.S.; Giorgi, F. Climate change hotspots in the CMIP5 global climate model ensemble. Clim. Chang. 2012, 114, 813-822. [CrossRef] [PubMed]

61. Taylor, K.E.; Stouffer, R.J.; Meehl, G.A. A Summary of the Cmip5 Experiment Design; PCDMI Report. 2009. Available online: https://pcmdi.llnl.gov/mips/cmip5/docs/Taylor_CMIP5_design.pdf (accessed on 26 October 2020).

62. Taylor, K.E.; Stouffer, R.J.; Meehl, G.A. An overview of cmip5 and the experiment design. Bull. Am. Meteorol. Soc. 2012, 93, 485-498. [CrossRef]

63. Hidalgo, H.G.; Amador, J.A.; Alfaro, E.J.; Quesada, B. Hydrological climate change projections for central america. J. Hydrol. 2013, 495, 94-112. [CrossRef] 
64. Hidalgo, H.; Alfaro, E.; Quesada-Montano, B. Observed (1970-1999) climate variability in central america using a high-resolution meteorological dataset with implication to climate change studies. Clim. Chang. 2017, 141, 13-28. [CrossRef]

65. Maurer, E.P.; Roby, N.; Stewart-Frey, I.T.; Bacon, C.M. Projected twenty-first-century changes in the central american mid-summer drought using statistically downscaled climate projections. Reg. Environ. Chang. 2017, 17, 2421-2432. [CrossRef]

66. Depsky, N.; Pons, D. Meteorological droughts are projected to worsen in Central America's Dry Corridor throughout the 21st century. Environ. Res. Lett. 2020. [CrossRef]

67. Hidalgo, H.G.; Alfaro, E.J.; Amador, J.A.; Bastidas, Á. Precursors of quasi-decadal dry-spells in the central america dry corridor. Clim. Dyn. 2019, 53, 1307-1322. [CrossRef]

68. Moss, R.H.; Edmonds, J.A.; Hibbard, K.A.; Manning, M.R.; Rose, S.K.; Van Vuuren, D.P.; Carter, T.R.; Emori, S.; Kainuma, M.; Kram, T.; et al. The next generation of scenarios for climate change research and assessment. Nature 2010, 463, 747-756. [CrossRef] [PubMed]

69. Van Vuuren, D.P.; Edmonds, J.; Kainuma, M.; Riahi, K.; Thomson, A.; Hibbard, K.; Hurtt, G.C.; Kram, T.; Krey, V.; Lamarque, J.-F.; et al. The representative concentration pathways: An overview. Clim. Chang. 2011, 109, 5. [CrossRef]

70. Smith, S.J.; Wigley, T. Multi-gas forcing stabilization with minicam. Energy J. 2006, 373-391. [CrossRef]

71. Clarke, L.; Edmonds, J.; Jacoby, H.; Pitcher, H.; Reilly, J.; Richels, R. Scenarios of Greenhouse Gas Emissions and Atmospheric Concentrations; US Department of Energy Publications: Washington, DC, USA, 2007.

72. Wise, M.; Calvin, K.; Thomson, A.; Clarke, L.; Bond-Lamberty, B.; Sands, R.; Smith, S.J.; Janetos, A.; Edmonds, J. Implications of limiting co2 concentrations for land use and energy. Science 2009, 324, 1183-1186. [CrossRef]

73. Thomson, A.M.; Calvin, K.V.; Smith, S.J.; Kyle, G.P.; Volke, A.; Patel, P.; Delgado-Arias, S.; Bond-Lamberty, B.; Wise, M.A.; Clarke, L.E.; et al. Rcp4. 5: A pathway for stabilization of radiative forcing by 2100. Clim. Chang. 2011, 109, 77. [CrossRef]

74. Edenhofer, O.; Pichs-Madruga, R.; Sokona, Y.; Kadner, S.; Minx, J.C.; Brunner, S.; Agrawala, S.; Baiocchi, G.; Bashmakov, I.A.; Blanco, G.; et al. Technical summary. In Climate Change 2014: Mitigation of Climate Change; Cambridge University Press: Cambridge, UK, 2014.

75. Riahi, K.; Grübler, A.; Nakicenovic, N. Scenarios of long-term socio-economic and environmental development under climate stabilization. Technol. Forecast. Soc. Chang. 2007, 74, 887-935. [CrossRef]

76. Riahi, K.; Rao, S.; Krey, V.; Cho, C.; Chirkov, V.; Fischer, G.; Kindermann, G.; Nakicenovic, N.; Rafaj, P. Rcp 8.5-A scenario of comparatively high greenhouse gas emissions. Clim. Chang. 2011, 109, 33. [CrossRef]

77. Thrasher, B.; Nemani, R. NEX-GDDP: Global Daily Downscaled Projections for Studies of Climate Change Impacts. 2015. Available online: https://esgf.nccs.nasa.gov/esgdoc/NEX-GDDP_Tech_Note_v0.pdf (accessed on 26 October 2020).

78. Wood, A.W.; Maurer, E.P.; Kumar, A.; Lettenmaier, D.P. Long-range experimental hydrologic forecasting for the eastern united states. J. Geophys. Res. Atmos. 2002, 107, doi:10.1029/2001JD000659. [CrossRef]

79. Wood, A.W.; Leung, L.R.; Sridhar, V.; Lettenmaier, D. Hydrologic implications of dynamical and statistical approaches to downscaling climate model outputs. Clim. Chang. 2004, 62, 189-216. [CrossRef]

80. Maurer, E.P.; Hidalgo, H.G. Utility of daily vs. monthly large-scale climate data: An intercomparison of two statistical downscaling methods. Hydrol. Earth Syst. Sci. 2008, 12, 501-563. [CrossRef]

81. Thrasher, B.; Maurer, E.P.; McKellar, C.; Duffy, P. Technical note: Bias correcting climate model simulated daily temperature extremes with quantile mapping. Hydrol. Earth Syst. Sci. 2012, 16, 3309-3314. [CrossRef]

82. Castillo, R.; Montero, R.; Amador, J.; Durán, A.M. Cambios futuros de precipitación y temperatura sobre américa central y el caribe utilizando proyecciones climáticas de reducción de escala estadística. Rev. Climatol. 2018, 18, 1-12.

83. Wilcox, R.R. Fundamentals of Modern Statistical Methods: Substantially Improving Power and Accuracy; Springer Science \& Business Media: New York, NY, USA, 2010. [CrossRef]

84. Amador, J.A.; Anderson, M.J.; Calderón, B.; Pribyl, K. The October 1891 Cartago (Costa Rica) floods from documentary sources and 20CR data. Int. J. Climatol. 2018, 38, 4830-4845. [CrossRef]

85. Ortiz-Malavasi, E. Atlas digital de costa rica (cr 2014). Investig. TEC 2015, 23, 1659-3383.

86. Hidalgo, H.G.; Alfaro, E.J. Skill of cmip5 climate models in reproducing 20th century basic climate features in central america. Int. J. Climatol. 2015, 35, 3397-3421. [CrossRef] 
87. Vecchi, G.A.; Soden, B.J.; Wittenberg, A.T.; Held, I.M.; Leetmaa, A.; Harrison, M.J. Weakening of tropical Pacific atmospheric circulation due to anthropogenic forcing. Nature 2006, 441, 73-76. [CrossRef]

88. Bony, S.; Bellon, G.; Klocke, D.; Sherwood, S.; Fermepin, S.; Denvil, S. Robust direct effect of carbon dioxide on tropical circulation and regional precipitation. Nat. Geosci. 2013, 6, 447-451. [CrossRef]

89. He, J.; Soden, B.J. Anthropogenic weakening of the tropical circulation: The relative roles of direct CO2 forcing and sea surface temperature change. J. Clim. 2015, 28, 8728-8742. [CrossRef]

90. Fuentes-Franco, R.; Coppola, E.; Giorgi, F.; Pavia, E.G.; Diro, G.T.; Graef, F. Inter-annual variability of precipitation over southern mexico and central america and its relationship to sea surface temperature from a set of future projections from cmip5 gcms and regcm 4 cordex simulations. Clim. Dyn. 2015, 45, 425-440. [CrossRef]

91. Parry, M.; Canziani, O.F.; Palutikof, J.P.; van der Linden, P.J.; Hanson, C.E. Climate Change 2007: Impacts, Adaptation and Vulnerability; Cambridge University Press: Cambridge, UK, 2007; Volume 4.

92. Ruiz, D.; Moreno, H.A.; Gutiérrez, M.E.; Zapata, P.A. Changing climate and endangered high mountain ecosystems in Colombia. Sci. Total Environ. 2008, 398, 122-132. [CrossRef] [PubMed]

93. Büntgen, U.; Martínez-Peña, F.; Aldea, J.; Rigling, A.; Fischer, E.M.; Camarero, J.J.; Hayes, M.J.; Fatton, V.; Egli, S. Declining pine growth in Central Spain coincides with increasing diurnal temperature range since the 1970s. Glob. Planet. Chang. 2013, 107, 177-185. [CrossRef]

94. Skliris, N.; Zika, J.D.; Nurser, G.; Josey, S.A.; Marsh, R. Global water cycle amplifying at less than the Clausius-Clapeyron rate. Sci. Rep. 2016, 6, 1-9. [CrossRef] [PubMed]

Publisher's Note: MDPI stays neutral with regard to jurisdictional claims in published maps and institutional affiliations.

(C) 2020 by the authors. Licensee MDPI, Basel, Switzerland. This article is an open access article distributed under the terms and conditions of the Creative Commons Attribution (CC BY) license (http:/ / creativecommons.org/licenses/by/4.0/). 